\title{
QUALITY OF FAMILY INTERACTIONS AND ADOLES- CENTS' PERSONALITY TRAITS
}

\section{Tamara Efendić-Spahić ${ }^{1}$}

The Faculty of Philosophy in Tuzla, University of Tuzla
Original scientific paper

UDC: $159.922 .8: 316.356 .2: 173.3$

Received: 06.02.2013

Accepted: 23.02.2013

\begin{abstract}
Family as the basic social unit is the primary environment of the development of an individual. In the family setting an individual satisfies (or should satisfy) the basic human needs such as the need for safety and love. In the studies of patterns of unadapted behavior of children and adolescents, temperament is most often stated as the key human characteristic feature that is the most important predictor in the development of unadapted and antisocial forms of behavior. The survey of dispositional empirically identified and inheritance-determined characteristics has been described in detail by Eysenck's dimensional model of personality through mutually orthogonal and bipolar characteristics: Neuroticism, Extraversion and Psychoticism. The formation of these dispositional characteristics is closely related to parents' sensitivity to child's needs and the level of parents' engagement in their parental role. Therefore, the aim of this research was to examine to what extent the assessment of the quality of the relationship with parents is an important predictor for explaining the basic dimensions of adolescents' personalities. The research was conducted on an appropriate sample of 135 adolescents, students of the Faculty of Philosophy in Tuzla. The results confirm that the aspects of negative relationships with mother and father are important predictors for explaining dimensions of Neuroticism and Psychoticism, which are very significant correlations of unadapted and antisocial behavior. Also, the results indicate less significant importance of positive relations with mother and father for explaining dependent research variables since it is presumed that positive relations act more as a protective factor whereas the assessment of negative relationships with parents is certainly more important, especially for the dimensions related to bad adaptation of adolescents. The results also indicate equal importance of mother and father in the upbringing process for explaining the basic personality dimensions of adolescents since negative relationships with both mother and father appear as equally important predictors for explaining the dimensions of Neuroticism and Psychoticism in adolescents.
\end{abstract}

Keywords: family, temperament, adolescence, Eysenck's model of personality, adaptation

\section{INTRODUCTION}

Vukasovic (1997) states that family is the basic social community, the first and primary social community, and as such it is the basic foundation for the life of every individual. The psychological importance of family has always been emphasized, and the beginnings of studying the mechanisms of its influence on an individual can be seen in psychoanalysis. Sigmund Freud (in Krstic, 1996) placed most of the basic theoretical terms into the context of family.

\footnotetext{
${ }^{1}$ Correspondence to:

Tamara Efendić-Spahić, The Faculty of Philosophy in Tuzla, University of Tuzla

T. Markovića 1, Tuzla, B\&H.

Phone: 0038735252187

E-mail: tamara.efendic-spahic@untz.ba
} 
Namely, according to this author the structure of personality and the patterns of the later behavior as well as the adaptation are largely the result of the parent - child relationship. Adler (in Krstic, 1996) also analyzed family as the basic pattern of interpersonal and social relations, especially emphasizing that the consequences of these relations target children.

If every child who lives in a family up to the age of two gets attached to the known guardian, the quality of that connection is different from child to child. The technique of an unknown situation is the most frequently used procedure for the evaluation of the quality of attachment of children aged one to two. Based on the behavior of child in a strange situation, aimed at evaluating the quality of attachment, Bowlby (1973) distinguishes two basic types of attachment:

a) Secure attachment - the children who developed secure attachment to the parent or guardian in an unknown situation show clear signs of separation anxiety when the contact with the mother is broken. However, when they stay alone, they do not show the signs of worrying as they believe that the mother will return. If such worry exists, an unknown person can comfort them.

b) Insecure attachment - this form of attachment can be identified by two behavior forms. In the first case child avoids insecurity in a way that he/she does not look for mother's closeness at all. In the second case an ambivalent insecurity appears -child expresses an intense reaction to mother's leaving by separation anxiety, but child also opposes to the contact when mother returns.

Lacković-Grgin (2006) states that attachment theory aims at explaining the tendency of human beings to develop strong emotional relations to others, and it offers a proper theoretical framework for understanding why some individuals have difficulties in developing and keeping a satisfactory relationship in adulthood. Within the attachment theory there are two basic hypotheses that make the theoretical concept of the attachment concept:

a) attached behavior is a characteristic of human beings during their entire lives,

b) attachment patterns in childhood in the parent - child relationship determine the quality of relationships at a later age.
Every relationship in adulthood has a possibility to become attached, provided it satisfies the following three conditions:

1.) existence of desire for the closeness of the person we are attached to,

2.) sense of security as a consequence of the contact with the person we are attached to,

3.) sense of agitation or discomfort which appears because of the separation or loss of the object of attachment.

Although there are differences in the attached relationships in childhood and adulthood,the dynamics is the same (Bartholomew, 1993, adopted from Lacković-Grgin and Ćubela-Andorić 2006). In order to differentiate the attached relationships from the unattached, it is necessary to emphasize three functions that such relationship needs to have. Every relationship that is to be marked as attached needs to include the tendency of a person to stay close to the attached person, especially if he/she is in a threatening situation, or the situation is threatening to his/her relationship with the attached person. A close attached relationship shall be every relationship that offers safe haven during illness, danger, or threats. In other words, person uses close attached relationship as sanctuary, protection, and support. An attached relationship must also be a secure base that will allow unlimited exploration of the world.

\section{Family interactions and other behavior}

Berk (2008) states that psychoanalytical and etiological theories describe that inner feelings of affection and safety, which are consequences of a healthy relationship of attachment, have favorable effects on all the aspects of psychological development. The continuity of care about child determines a relation between the quality of attachment and later development (Lamb et al. 1985, Thompson 2000, in Berk, 2008). Vasta, Haith, and Miller (1999) claim that the main issue in research into attachment is related to the effects of secure and insecure attachment on other aspects of child's functioning. A number of research proved that securely attached children show many positive characteristics that are not shown by children whose relationship with guardian is of lower quality. One of these qualities is child's cognitive competence. Several experiments showed that securelyattached children are later more successful at solving problems. 
(Frankel and Bates, 1990, Jacobsen et al. 1994, Matas et al. 1978, in Vasta, Haith and Miller 1999). Securely attached children are also more curious and prone to explorative behavior than other children (Hazel and Durett, 1982, Slade, 1987, adopted fromVasta, Haith and Miller, 1999). Finally, one research showed that cognitive competence of four-year-old children can be predicted based on their mothers' sensitivity towards them (and probably the quality of their attachment) at the age of three months (Lewis 1993, in Vasta, Haith and Miller, 1999). It seems that securely attached children are socially more competent. They are more willing to cooperate and more disciplined, and have better relations with their peers (Jacobson and Willow, 1986, Londerwille and Main, 1981, Pastor 1981, in Vasta, Haith and Miller,1999). These researches indicaterelatively clearly that classification of children by the procedure of exploring in an unknown situation can be useful in predicting child's later cognitive and emotional competence. It is possible that, as a result of the fact that child feels secure in the presence of guardian, he/she feels more secure in exploring his/her social and physical surrounding, thus developing important social and cognitive skills. Berk (2008) claims that when parents react to their child with sensitivity, not only during nursing but also later, child shall probably develop well.

\section{Research aims}

The main aim of the research is to study how adolescents perceive their relationships with their parents, and whether there is a connection between the adolescents' perception of relations with father and mother and their basic personality traits. According to the existing research into the relationship between parents and their children (Bolby, 1973; Lacković-Grgin, 1994, Smojver-Ažić, 1999), it is justifiable to expect that the perception of relationships with parents plays an important role in adaptive behavior of adolescents. The results of the research into the perception of relationships with parents (Bezinović, 2000; Kuburić, 2001; Vulić-Prtorić, 2002) indicate that appropriate relationships with parents are the most significant protective factor in the development of children and adolescents, and that they play an important role in shaping the personality traits of adolescents.
Therefore, in accordance to the theoretical premises and the past research into the role and importance of parents to the development of individual, the aim of this research is aimed at examining the correlation of adolescents' perceived relationship with parents and their basic personality traits.

\section{Research problems}

In accordance to the research aims, the following research problems have been identified:

1. To examine the perceived relationships with parents in the group of young men and women;

2. To determine to what extent the basic personality traits - Extraversion, Introversion, Psychotisicm, can be explained by the facets of perception of positive and negative relationship with mother and father;

3. To determine whether the evaluations of the relationship with the parent of the same sex are more predictive for the explanation of basic personality traits, or the domination of mother's parental characteristics remains stable during the adolescent period.

\section{Hypotheses}

In accordance to the existing theoretical concepts about the importance of perception of the relationship with parents, the main research hypotheses have been postulated:

1. Regarding the fact that personality traits of children are closely related to parents' sensitivity to child's needs, it is expected that the elements of perception of positive relations with mother and father as a protective factor will be significant for the explanation of Extraversion dimension and Emotional stability, while the elements of perception of negative relations with mother and father will prove to be significant predictors for the dimension of Psychoticism and Neuroticism.

2. Regarding the fact that in our culture mother's parental role is dominant in terms of taking care of children regardless of their development stage, the elements of perception of the relationship with mother are expected to be more significant predictors for explaining dependant research variables. 


\section{RESEARCH METHODOLOGY}

\section{Subjects}

The research included a randomsample of 135 subjects: 81 girls and 54 young men, students at Tuzla University, aged 19 to 21 . All the subjects come from the complete families, they live with their parents of guardians, and the equal number of them live in urban and rural places.

\section{Research instruments}

With the purpose of testing the research hypotheses, the following research instruments were used:

1. Questionnaire of past relationships with parents (Smojver-Ažić, 1999)

2. Questionnaire of present relationships with parents (Smojver-Ažić, 1999)

3. Eysenck Personality Questionnaire -EPQ (1994)

\section{Procedure}

The data collection lasted for two months. The questioning was voluntary and anonymous. The questioning was conducted in smaller groups, up to 20 subjects, so that they are provided with time for work and the necessary privacy. The time for filling in the questionnaire was not limited, and it lasted between 60 and 90 minuteson average. All the subjects were given standardized instructions for work.

\section{RESULTS}

The first step in data processing was the calculation of mean values and dispersion indices for independent and dependent variables, followed by determining reliability coefficient for every research variable. The results are given in the following tables.

Table1. Mean values and dispersion indices for evaluations of past and present relationships with parents

\section{Mean values and dispersion indices of perception of relationships with parents}

Total result on the subscale care-father

Total result on the subscale care-mother

Total result on the subscale perception of support from father

Total result on the subscale perception of support from mother

Total result on the subscale control-father

Total result on the subscale rejection-father

Total result on the subscale control-mother

Total result on the subscale rejection-mother

Total result on the subscale negative relations towards father

Total results on the subscale negative relations towards mother
Std.

N M deviation

$\begin{array}{lll}126 & 70.79 & 13.92 \\ 129 & 77.57 & 12.44\end{array}$

$131 \quad 40.46 \quad 9.60$

$132 \quad 43.64 \quad 7.37$

$127 \quad 20.64 \quad 7.06$

$\begin{array}{lll}132 & 2.89 & 3.29\end{array}$

$\begin{array}{lll}126 & 22.21 \quad 7.07\end{array}$

$\begin{array}{lll}129 & 27.49 & 17.39\end{array}$

$131 \quad 30.20 \quad 21.03$

$129 \quad 25.65$ 


\begin{tabular}{|cccc} 
Mean values and dispersion indices of basic personality traits & $\mathbf{N}$ & $\mathbf{M}$ & $\begin{array}{c}\text { Std. } \\
\text { deviation }\end{array}$ \\
\hline Extroversion & 132 & 21.14 & 4.04 \\
Psychoticism & 132 & 6.15 & 2.34 \\
Neuroticism & 132 & 11.63 & 4.03 \\
\hline
\end{tabular}

Table 3. Reliability coefficients for every scale/subscale (Cronbach alpha)

\begin{tabular}{ccc}
\hline Scale/subscale name & Particle number & alpha \\
\hline Control - father & 11 & 0.728 \\
Rejection - father & 5 & 0.779 \\
Control - mother & 11 & 0.726 \\
Rejection - mother & 5 & 0.733 \\
Negative relationships - father & 29 & 0.942 \\
Negative relationships - mother & 29 & 0.926 \\
Care - father & 23 & 0.918 \\
Care - mother & 23 & 0.882 \\
Perception of support - father & 13 & 0.901 \\
Perception of support - mother & 13 & 0.901 \\
Extroversion & 30 & 0.685 \\
Psychoticism & 25 & 0.418 \\
Neuroticism & 21 & 0.815 \\
\hline
\end{tabular}

Table 4. Multiple regression analysis of perceived relationships with father (predictor variables) and personality traits of subjects (criteria variables)

\begin{tabular}{|c|c|c|c|c|c|c|c|c|c|}
\hline \multirow{2}{*}{$\begin{array}{c}\text { Predictors } \\
\text { (father) }\end{array}$} & \multicolumn{3}{|c|}{ Extroversion } & \multicolumn{3}{|c|}{ Psychoticism } & \multicolumn{3}{|c|}{ Neuroticism } \\
\hline & beta & $\mathbf{t}$ & p & beta & $\mathbf{T}$ & $\mathbf{p}$ & beta & $\mathbf{t}$ & $\mathbf{p}$ \\
\hline Care & -0.112 & -0.62 & 0.537 & 0.277 & 1.565 & 0.855 & 0.262 & 1.51 & 0.135 \\
\hline Control & -0.208 & 1.443 & 0.156 & -0.028 & -0.1 & 0.846 & 0.047 & 0.341 & 0.734 \\
\hline $\begin{array}{l}\text { Rejection } \\
\text { Negative }\end{array}$ & 0.117 & 0.888 & 0.377 & -0.054 & & 0.677 & -0.189 & 1.498 & 0.138 \\
\hline $\begin{array}{l}\text { Relationships } \\
\text { Perception }\end{array}$ & 0.05 & 0.27 & 0.788 & 0.447 & 2.481 & $0.015^{*}$ & 0.55 & 3.115 & $0.003 * *$ \\
\hline Of support & 0.02 & $\begin{array}{c}0.119 \\
\mathbf{R}=\mathbf{0 . 2 9 8} \\
\mathbf{R}^{\mathbf{2}}=\mathbf{0 . 0 8 9}\end{array}$ & $\begin{array}{c}0.906 \\
\mathbf{F}=\mathbf{1 . 6 5 1} \\
\mathbf{p}=\mathbf{0 . 1 5 5}\end{array}$ & 0.072 & $\begin{array}{c}0.435 \\
\mathbf{R}=\mathbf{0 . 3 6 0} * \\
\mathbf{R}^{\mathbf{2}}=\mathbf{0 . 1 3 0}\end{array}$ & $\begin{array}{c}0.665 \\
F=\mathbf{2 . 5 3 6} \\
\mathbf{p}=\mathbf{0 . 0 3 4}\end{array}$ & 0.005 & $\begin{array}{c}0.033 \\
\mathbf{R}=\mathbf{0 . 4 0 5} * * \\
\mathbf{R}^{\mathbf{2}}=\mathbf{0 . 1 6 4}\end{array}$ & $\begin{array}{c}0.974 \\
F=\mathbf{3 . 3 3 4} \\
\mathbf{p}=\mathbf{0 . 0 0 8}\end{array}$ \\
\hline
\end{tabular}

$*$ significance level with the risk of 5\% $\quad * *$ significance level with the risk of $1 \%$

Perceived relationships with father did not prove to be significant predictors for the dimension of Extroversion ( $\mathrm{R}=0.298$; $\mathrm{p}=0.089)$, but the perceived relationships with father are significant predictors for the dimension of Psychoticism $(\mathrm{R}=0.360 ; \mathrm{p}=0.034)$, although the perception of relationships with father can explain only $13.4 \%$ of psychoticism variance.
The dimension of perception of negative relationships with father proved to be a significant predictor for Psychoticism ( $=0.447$; $\mathrm{t}=2.481 ; \mathrm{p}=0.015$ ). Our results are consistent with the results of some similar research (Patock-Peckham and Morgan-Lopez, 2009) which found that authoritative parenthood of fathers has a protective effect on the feeling of reject 
ion by father, which is for example important for the absence of depression symptoms in adolescents, regardless of their sex.However, these authors also state that parental influence, especially at an early adolescent age, is multifaceted and very complex. Perceived relationships with father proved to be significant predictors for Neuroticism of adolescents as well $(\mathrm{R}=0.405, \mathrm{p}=0.008)$, although perceived relationships with father can explain only $16.4 \%$ of Neuroticism variance. It is interesting that the dimension of perception of negative relationships with father ( $=0.55 ; \mathrm{t}=3.115 ; \mathrm{p}=0.003$ ) stands out as the most significant predictor for Neuroticism and Psychoticism of adolescents.

Table 5. Multiple regression analysis of perceived relationships with mother (predictor variables) and personality traits of subjects (criteria variables)

\begin{tabular}{|c|c|c|c|c|c|c|c|c|c|}
\hline \multirow{2}{*}{$\begin{array}{c}\text { Predictors } \\
\text { (mother) }\end{array}$} & \multicolumn{3}{|c|}{ Extroversion } & \multicolumn{3}{|c|}{ Psychoticism } & \multicolumn{3}{|c|}{ Neuroticism } \\
\hline & beta & $\mathbf{t}$ & p & beta & $\mathbf{T}$ & $\mathbf{p}$ & beta & $\mathbf{t}$ & $\mathbf{p}$ \\
\hline Care & 0.137 & 0.813 & 0.419 & -0.065 & 0.422 & 0.675 & 0.031 & 0.199 & 0.843 \\
\hline Control & -0.277 & 1.693 & 0.095 & 0.239 & 1.604 & 0.113 & 0.232 & 1.528 & 0.131 \\
\hline $\begin{array}{l}\text { Rejection } \\
\text { Negative }\end{array}$ & 0.029 & 0.209 & 0.835 & 0.032 & 0.257 & 0.798 & -0.106 & 0.83 & 0.409 \\
\hline $\begin{array}{l}\text { Relationships } \\
\text { Perception }\end{array}$ & 0.026 & 0.157 & 0.876 & 0.357 & 2.339 & $0.022^{*}$ & 0.398 & 2.556 & $0.013 *$ \\
\hline Of support & -0.232 & $\begin{array}{c}1.0203 \\
\mathbf{R}=\mathbf{0 . 2 2 6} \\
\mathbf{R}=\mathbf{0 . 0 5 1}\end{array}$ & $\begin{array}{c}0.233 \\
F=\mathbf{0 . 7 0 8} \\
p=\mathbf{0 . 6 1 9}\end{array}$ & 0.092 & $\begin{array}{c}0.525 \\
\mathbf{R}=\mathbf{0 . 4 6 4} * * \\
\mathbf{R}=\mathbf{0 . 2 1 6}\end{array}$ & $\begin{array}{c}0.601 \\
F=\mathbf{3 . 6 3 1} \\
\mathbf{p}=\mathbf{0 . 0 0 6}\end{array}$ & 0.138 & $\begin{array}{c}0.769 \\
\mathbf{R}=\mathbf{0 . 4 2 6} * \\
\mathbf{R}=\mathbf{0 . 1 8 2}\end{array}$ & $\begin{array}{c}0.444 \\
\mathbf{F}=\mathbf{2 . 9 2 7} \\
\mathbf{p}=\mathbf{0 . 0 1 9}\end{array}$ \\
\hline
\end{tabular}

*significance level with the risk of 5\%

Perceived relationships with mother did not prove to be significant predictors for Extroversion of adolescents $(\mathrm{R}=0.226, \mathrm{p}=0.619)$, but they did prove significant for Psychoticism $(\mathrm{R}=0.464 ; \mathrm{p}=0.006)$ and Neuroticism $(\mathrm{R}=0.426$; $\mathrm{p}=0.019)$. Thus, perceived relationships with mother can cover $21.6 \%$ of the result variance in the dimension of Psychoticism and $18.2 \%$ of the result variance in the dimension of Neuroticism of their children. It is interesting that perception of negative relationships with mother stands as a significant predictor for Neuroticism and Psychoticism of adolescents ( $=0.357 ; \mathrm{t}=2.339 ; \mathrm{p}=0.022$ for Psychoticism; $=0.398 ; \mathrm{t}=2.556 ; \mathrm{p}=0.013$ for Neuroticism). Concerning the fact that the dimension of perception of negative relationships most frequently appeared as the most significant predictor in multiple regression analysis, it can be said that this aspect of perception of relationships with parents stands out as most predictive for explanation of Neuroticism and Psychoticism of adolescents. It is important that the relation with parents in the adolescent period reflects the quality of relationships from the previous development stages. The modification is that in adolescence this relation achieves its final effect on personality traits, image of self, but also **significance level with the risk of $1 \%$

the forms of behavior that individual will carry as an internalized part of personality and relations to important others during the entire life.

\section{CONCLUSIONS}

By analyzing the correlation between perception of positive and negative relationships with parents and basic personality traits on a random sample of 135 subjects, students at the Faculty of Philosophy, Tuzla University, the following conclusions were made:

1. Perceived relationships with mother and father proved to be significant predictors for explaining the dimensions of Psychoticism and Neuroticism. Dimensions of negative relationships with mother and father stand out as the most significant predictors for explaining dependant variables.

2. Perception of relationships with mother and father did not prove to be a significant predictor for explaining Extroversion of adolescents. Therefore, the part of hypothesis related to the connection of positive relationships with parents and the dimension of Extroversion is rejected. 
3. On the basis of the proportion of predictor variables in explaining the basic personality traits of adolescents, it can be concluded that positive aspects of relationships with parents are not significant in explaining the basic personality traits of adolescents. They act more as a protective factor, while the aspects of negative relationships with mother and father are more significant for explaining Neuroticism and Psychoticism, dimensions closely related to adolescents' adaptation.

4. Although it is considered that mother's dominance in upbringing within our culture is principal regardless of child's development stage, the results of this research clearly indicate that the aspects of negative relationships with mother and father are equally significant predictors for the dimensions of Neuroticism and Psychoticism. Therefore, the hypothesis about higher predictability of perceived relationships with mother in explaining the basic personality traits of adolescents is rejected.

\section{REFERENCES}

Berk, L. (2008). Psihologija cjeloživotnog razvoja [Psychology lifelong development], Jastrebarsko, Croatia: Naklada Slap.

Bezinović, P. \& Smojver-Ažić, S. (2000). Negativni odnos roditelja i agresivnost adolescenata: uloga spola roditelja i spola adolescenta [The negative relationship between parents and aggressiveness of adolescents: the role of sex of parents and sex of adolescent], Hrvatska revija za rehabilitacijska istraživanja vol. 36 , broj 1, str.87-98

Bowlby, J. (1973). Attachment and Loss: Separation. Basic Books, New York
Eysenckov upitnik ličnosti - priručnik za ocjenjivanje [Eysenck Questionnaire of personality - a manual for evaluation], (1994). Jastrebarsko, Croatia: Naklada Slap.

Grgin-Lacković, K. (1994). Samopoimanje mladih [Selfimage of young], Jastrebarsko, Croatia: Naklada Slap.

Grgin-Lacković, K. (2006). Psihologija adolescencije [Psychology of adolescence], Jastrebarsko, Croatia: Naklada Slap.

Halmi, A. (2003). Multivarijatna analiza u društvenim znanostima [Multivariatn analysis in the social sciences], Zagreb, Croatia: Alinea.

Krstić, D. (1996). Psihološki rječnik [Psychological dictionary], Belgrade, Serbia: Zavod za udžbenike i nastavna sredstva.

Kuburić, Z. (2001). Porodica i psihičko zdravlje djece [Family and mental health of children], Belgrade, Serbia: Čigoja štampa.

Lacković-Grgin, K. \& Ćubela-Andorić, V. (2006). Odabrana poglavlja iz psihologije odraslih [Selected chapters from psychology of adults].

Patock-Peckham, J.A. \& Morgan-Lopez, A.A. (2009). The gender specific mediational pathways between parenting styles, neuroticism, pathological reasons for drinking, and alcohol-related problems in emerging adultthood, Adictive Behaviors, 34, 312-315.

Smojver-Ažić, S. (1999). Privrženost roditeljima, te separacija-individualizacija kao odrednice psihološke prilagodbe studenata [Devotion parents, and separation-individualization as determinants of psychological adjustment of students], Doktorska disertacija, Zagreb, Croatia: Filozofki fakultet, Sveučilište u Zagrebu.

Vasta, R, Haith, M. M. \& Miller A.S. (1998). Dječija psihologija [Psychology of children], Jastrebarsko, Croatia: Naklada Slap.

Vukasović, A. (1999). Obitelj - vrelo i nositeljica života [Family - the source and bearer of life], Zagreb, Croatia: Hrvatski katolički zbor «Mi»

Vulić-Prtorić, A. (2002). Obiteljske interakcije i psihopatološki simptomi u djece i adolescenata [Family interaction and psychopathological symptoms in children and adolescents. Contemporary psychology], Suvremena psihologija 5, 1, 31-51. 